\title{
Shaiva-Siddhanta (Philosophy of Shaivism) and Its Social Aspect
}

\author{
Elena Anikeeva \\ Peoples' Friendship University of Russia \\ 6 Miklukho-Maklaya St., Moscow, 117198, Russia \\ hotkovskaya7@gmail.com
}

\begin{abstract}
Shaiva-siddhanta - a profound and elaborated Religious and Philosophical Hindus system that emerged in South India (Tamil Nadu). Shaiva-siddhanta got the ambiguous status in orthodox Hinduism because of socio-caste structure rooted in medieval India and ethno-cultural dispositions between Indian South and Indian North. Social problems put their indelible marks on development and status of Shaiva-siddhanta: it is not included in the list of orthodox Hindus astika Philosophical systems/darshanas. Many of siddhantin authors belonged to shudras and untouchables; Meykandar, the author of one of the sources of this system "Sivajnanabodha" was learned shudra. "Sivajnanabodha" as a high sophisticated treatise of Indian theistic tradition (Icvaravada) resembles some opuses of Nyaya darshana especially in argumentation in favor of God's (Icvara's, Hara's) existing. Social background of Shaiva-siddhanta became the main reason not to associate it with astika darshanas. Shaivasiddhanta seems to be the crossroad between Nigama and Agama, Indian North and Indian South, the Aryans and Dravidians, Brahmins and inferior casts.
\end{abstract}

Keywords-Shaiva-siddhanta; Agamas, Tamil Veda; astika; caste (jati); twice-born (dvidja) castes; shudra; Indian theism (Icvara-vada)

\section{INTRODUCTION}

The systems of Eastern Thought such as Shaivasiddhanta need first to read, translate, then interpret, compare and categorize (in possible extend) through Western notions. Scholars paid little attention to Shaiva-siddhanta, notwithstanding its profoundness; its literary sources are in the first step of introducing into academic circles. Comparing to well-known Hindus darshanas (like Vedanta and so on) Shaiva-siddhanta deserves gradually more interest and conceiving.

Saiva-siddhanta, in Sanskrit, "perfect, completed teaching of Shaivism" definitely expresses the theistic trend in Indian Philosophy. General feature of theism, including Eastern theism is teaching about Personal God. The peculiarity of Indian theism (Icvara-vada) consists in completing the opposite trend - doctrine of impersonal Absolute, primarily, advaita-vedanta. Conceiving the Deity or soteriological ideal both personal and impersonal Indian thinkers look like harmonizing these trends in metaphysics [1]. However, in social relations there occurred some conflicts around Indian theistic trends. Vedanta and advaita- vedanta had fashioning the orthodox Hindus viewpoint, which is as a rule, represented by higher Brahmins. To the contrary, many democratic tendencies appeared on the agenda under the cover of one or another theistic outlook, e.g. bhakti and Shaiva-siddhanta. Lower Varna's authors shudras and untouchables created some of siddhantin sources. Shaiva-siddhanta was not included in the list of orthodox Hindus astika Philosophical systems/darshanas. The cause of social conflict lies in pretention of Brahmins to dominate totally over the sphere of teaching and learning. Social inequality indicated Shaiva-siddhanta and determined its ambiguous status in Hinduism. Up to now, we observe social-caste conflicts, discrimination and related ethnocultural disposition between Indian South and Indian North, which had also reflected upon Shaiva-siddhanta. Caste discrimination is prohibited by Indian Constitution ( $\S 15)$. Researching in Shaiva-siddhanta's Philosophy, its social aspect, ideological struggle around it helps to answer the question why social life so differs from the ideal constitutional paragraph. The purpose of this paper is to demonstrate how caste and socio-cultural contradictions of ancient and modern India interfered with "pure" metaphysics of Shaiva-siddhanta.

\section{Difference Between Nigama and Agama}

Shaiva-siddhanta, as the 'perfect teaching of Shaivism', is a Religious and Philosophical system that emerged in South India (Tamil Nadu). Literary sources being at the same time sacred scriptures of Shaiva-siddhanta are of four parts.

1) Twenty-eight Agamas (Shaivagamas) - theological and ritualistic treatises dated around second half of I century B. C.;

2) Dominantly recognized Vedas;

3) "Meykandar's Shastras" systematically resumed in "Sivajnanabodha" ("The awaking knowledge about Shiva") of XIII-XIV century a. d.;

4) "Tirumuray" ("12 Sacred Selections"), or so called Tamil Veda, consisting Religious hymns of poets - nayanars belonged to Tamil bhakti movement in the 6th -12 th centuries a. d.

Basic sacred texts of Shaiva-siddhanta are Agamas; tension had performed between them and Vedas. Some sources of Shaiva-siddhanta have originated not from Aryan 
Brahmanism but from aborigine Indian culture. Agama means going apart, or besides orthodox Vedas which called Nigama - going along. Agamic literature recognized prima facie and eulogized by siddhantins, and they predominantly recognize Nigama tradition. Agamas divide in Shaivagamas, Vishnu Agamas and so on. Agamas appear to have some sort of heterodoxy relating to Nigama. Nevertheless, Agamas deserved high authority in aborigine Dravidian Religions and cults of South India, which had agglomerated in the form of medieval Hinduism in post-Vedic period. Meanwhile, Agamas were considering almost heretic and marginal from the side of "pure" northern Aryan Brahmins and Brahmanism.

General topics of Shaivagamas, written in Sanskrit a well as in the Tamil language and founding siddhantin Philosophy are soteriology, ritual and ascetics/yoga (which is inner ritual). No doubt, Agamic literature, which counts a huge scope of texts, called sometimes by common notion "Tantric literature", needs further investigation. Pierre-Sylvain Filliozat describing in 2008 the history of Agamic studies stressed their actuality, "In 1955, Jean Filliozat, my father, established a French Institute in Pondicherry. He invited Alain Danielou to his Department of Indology... Danielou came with Pandit N. R. Bhatt, who could be appointed at the same time and to whom Jean Filliozat entrusted the main project of his new institution: to collect manuscripts of Saiva texts of rituals, i.e. Saivagamas, survey the relevant literature and prepare critical editions with translations. He directed a team of pandits to organize an Agamic library to collate manuscripts. He could publish several major texts of Agamic literature... He has constituted a precious tool for researchers of the 21 st century, which will be the century of Tantric studies in the history of Indology" [2].

By the process of studying and enrolling of Agamic literature into the broader sphere of research there enforced an old ideological struggle between Indian South and Indian North, which interfered with Shaiva-siddhanta and covered it with some sort of dark shadow.

\section{SHAIVA-SidDHANTA: Social AND IDEOLOGICAL TENSIONS}

Why Shaiva-siddhanta got ambiguous status in Hinduism? As a deep philosophy and its possible influence on other systems, Shaiva-siddhanta seems to be the outstanding phenomenon in Indian culture, but its significance mainly ignored by scholars. Paranjoty V. pointed out strange situation why Shaiva-siddhanta deserved gradually less attention and research comparing to Hindus darshanas [3]. Moreover, Shaiva-siddhanta does not belong to Hindus darshanas: therefore, it also cannot be astika. On the other hand, Shaiva-siddhanta never called nastika, because it's a part of Hinduism (Shaivism). So, Shaiva-siddhanta situates in the realm of 'Between'. The ideological struggle between Indian South and Indian North may clarify the reason of this siddhantin paradox.

The ambiguity of siddhantin status resembles the status of Agamas inside Hinduism. Contemporary ideological battles show opposite axiological motivations from different sides: northern and southern scholars. As for Shaivagamas emerged in Indian Dravidian South, this fact promoted the growth of Dravidian ideology with its slogan "five thousand years of ancient and continuous Hindus tradition". Above mentioned N. R. Bhatt (1920-2009), one of the pioneers of Agamic studies who collected more than 15 thousand manuscripts and published many of them [see 4] ascertains: "On the basis of archaeological and literary evidence, it is possible to show that the religion persisted in India without a break at least from the pre-Vedic times up to the present day. Studies on the Mohenjo-Daro period show that there was a profound civilization of religion and culture...The rituals and practices found in the Agamas are not found in the Vedas" [5]. Along with many scholars, I agree with assertion that medieval and modern Hinduism with its basic archetypes and forms of cult such as puja and murti, which are quite different to Vedic hymns and Vedic yajna derives its constitution from Agamas, not from Vedas. However, I refuse the position about continuity between Mohenjo-Daro "proto-Shiva" (picture that resembles the icon of Shiva) and the later cult of Shiva in Agamic tradition. I think the identity of Mohenjo-Daro "proto-Shiva" and shaivism is under the question because of: a) the problem of deciphering the language of Hindus Valley culture; b) the problem to demonstrate Agamas's possible origin from Mohenjo-Daro civilization.

Northern Indian scholars do not agree with such acute assessments concerning shaivism as did southern researchers. The slogan of northern Indian ideology proclaims "pure origin from Vedic Aryans and their scriptures". Nevertheless, northern Indian scholars' goal does not seem to neglect totally Agamas or to withdraw them into sheer contradiction with Vedas, but... to reconcile them with Nigama (as common proverb says 'one kills another with one's fraternal embraces'). During a long history, according to the point of view of northern Brahmins, Agama and Nigama developed though in diversity but in agreement, not in contradiction. Dr. Rama Ghose as a remarkable representative of this trend has been studying and translating many of source books and original scriptures of Shaivasiddhanta, especially Siddhantagamas; she awarded some prizes for her research work. Dr. Rama Ghose achieved such a high estimation due to her efforts to explain SaivaSiddhanta authentically because of her profound knowledge of Tamil language, and knowledge of Tamil language, as says the author of the preface to one of her books "may be considered as rare distinction for a northern Indian scholar" [6]. Rama Ghose claims "Agamas and Vedas, never apart, rather complementary to each other, are the revelation by the Supreme for the welfare of mankind. Both are the sources and ground of all the philosophical doctrines and the religious life of Hinduism." [7]. To be honest, South Indian scholar N. R. Bhatt as well as northern Indian ones though insisted on sharp differences between Agama and Nigama stressed that Agamas are not 'antivedic' [8]. Yet, what is the cause of their tension?

The unity and diversity between southern and northern Indian trends of research expresses the unity and diversity of Hinduism itself. Mean, the distinction between two branches 
of Hinduism, different estimation and accentuation of Agama and Nigama and their co-relations lies not in the sphere of pure religious doctrine, but derives from social differences, which determine ideological battle between Indian South and Indian North. The status of Agamas and Shaiva-siddhanta depends on the problem of their social background. If we put a question about the origin of southern Indian Brahmins, we discover an interesting thing: some of them definitely would be non-Aryans. There were ancient pre-Aryan Dravidian priests and other learned people who might become Brahmins. This question is a subject of a future research in Indian studies and sociology. We think it would not be mistake to suggest that pre-Aryan Dravidian priests could create some Agamas, and these creations were for them 'ticket' to Hinduism, precisely made a room for them to be Brahmins. Further, we can infer that definitely not all Dravidian priests and learned people might become Brahmins. This proposal can clarify the cause of socio-caste conflicts and cultural tension between Indian South and Indian North, which pierced Shaiva-siddhanta.

The siddhantin situation is that Brahmins did not create its third and fourth literal and sacred sources. Moreover, the authors of these two sources were outsiders of twice-born (dvidja) castes. What were the religious inferences from this? In Hinduism, only twice-born casts might initiate Hindus Vedic rituals, extremely excluding shudras and untouchables. Up to now, social and religious status of shudras and untouchables is inferior and discriminative; humiliation of them appeals to social justice. However, Hindus religion puts severe chains over one-born people so as they paradoxically realize themselves as Hindus and do not want to release or to be outsiders of Hinduism. Because Hindus outlook explains social reality, i.e. cast division as natural, ontological necessity, which is not arbitrary, and not subject to human volition. I mean the law of karma - samsara as some kind of "moral-and-natural determinism" [9]. For every shudra or untouchable who are ritually "non-pure" in Hinduism, knows well that this law strictly determines his or her caste status, strictly prescribes exclusively his or her caste duties acknowledged as super-social. During the history, accidentally some groups of people through social struggle won superior status; other groups were throne to inferior one, meanwhile the laws of karma - samsara and caste division had never dismissed in Hinduism.

There is some difference between the non-Vedic Siddhantin sources. Agamas written partly in Sanskrit, partly in Tamil language might be more associated with Brahmins (Dravidian Brahmins or those who became, were becoming Dravidian Brahmins) than so-called Tamil Veda created exclusively by Dravidian non-Brahman authors in Tamil language. However, some verses from the forth literal and sacred source of Shaiva-siddhanta "Tirumuray" presenting religious poetry of nayanars adoring Shiva are still chanting in south Indian temples notwithstanding the lower social origin of verses' authors. Eminent philosopher of contemporary India K. Satchidananda Murty ${ }^{1}$ (1924-2011)

${ }^{1}$ Padma Vibhushan, the second-highest degree of Indian Government, awarded K. Satchidananda Murty. testifies that the authors of "Tirumuray" Appar, Sekkilar and Meykandar (himself!) belonged to Veḷlalia - a southern Indian social group qualified as shudras in orthodox Brahmanism. Anthropologists explain that Veḷlaļa (Pillai) are big multi-caste community and main population of Tamil South who did not submitted to Sanskritisation; they primarily were not servants, occupied various jobs, some of them were priests and landlords [10] [11]. The contradiction between Vedas and Tamil culture were growing from Sekkilar's (XII cent.) point of view who firstly in his "Periya Puranam" discharged northern Vedic scriptures glorifying Tamil heritage. This controversy becomes evident due to language, cultural and social oppositions. Besides, in democratic trend of bhakti (Shaivabhakti) many poets were illiterate because Sanskrit learning was the privilege of twice born.

The tension between the two cultures seems sharper in the biography of Meykandar, the author of the forth Siddhantin source Sivajnanabodha. This treatise ascribed to him but what was the original language of this work is a subject on which there is no scholarly consensus. Whether Meykandar translated it from Sanskrit into Tamil or conversely, it is difficult, if not impossible, to say now. At least, Sanskrit version of Sivajnanabodha is acknowledged. Then how could Meykandar who was a shudra (!) know Sanskrit or write in it? Learned shudras were out of official Hindus law and persecuted from ancient times (Maitri Upanishad. VII. 8-9). We propose that the destiny of Meykandar could be very sorrow and even tragic. Nevertheless, Sivajnanabodha preserved its perfectness, and its distinctive sophisticated manner shows elaborated Philosophy of a high level.

The content of Sivajnanabodha is theistic, and it stands near to orthodox Hindus darshana Nyaya - the system on the top of Indian theistic trend (Icvara-vada) [12]. Meykandar deals with different ways of argumentation in favor of God's (Icvara's, Shiva's, Hara's and so on) existing. Meylandar's discourse resembles the argumentation Udayanacharya ( $\mathrm{X}$ cent.) who belonged to Nyaya school. Learned shudra Meykandar did not concede high Brahmin (because of

'Acharya' title) Udayana in his philosophical skillfulness. Comparing arguments of the two authors, we find their close unanimity. Meykandar in "Sivajnanabodha". I (SJB) argues: "The world, animate and inanimate, passes through a cycle of three phases, evolution, maintenance, and dissolution... it must have an efficient cause. The efficient cause must be the Agent... the Supreme Deity (Hara)" [13]. Udayana's "Nyayakusumanjali".V. 2-3 ("Handful of blossoms (on the tree) of Nyaya"- NK): ("From effect" - karyatva): "The earth, must have had a Maker because they \{other natural elements in this row - water, fire etc. - E. A. $\}$ have the nature of 'effects' like a jar; by a thing's having a maker we mean that it is produced by some agent who possesses the wish to make" [14]. Meykandar not only admits the argument analogical to Udayana, but moreover both of them use the same term karyatva for the "world had been done" [15].

Both philosophers criticize the same opponents from other schools (nirIcvara-vadins - those who undermine 
Icvara's existence - mImamsakas etc.) and reach similar conclusions. Meykandar: "God causes the soul to experience the consequences of its previous works; the karmic principle cannot operate independently of the will of God (SJB. II. 2. a) [16]. Udayana: "Our proposition is that there exists a supernatural (alaukika) cause of another world (paraloka)2, i.e., a cause beyond the reach of the senses" (NK. I. 5-6) [17]. Alaukika and conscious cause conducting unconscious karma for Udayana is nothing but Icvara. We find that Meykandar follows in unison with Udayana. One may find moreover similarities between Sivajnanabodha and Nyayakusumanjali, between Shaiva-siddhanta and Nyaya. About probable influence of one school to another or one opus to another is a question of further research.

\section{CONCLUSION}

Shaiva-siddhanta, its Philosophy and social background need further investigation and research. Social aspect of Shaiva-siddhanta seems to be the crossroad between Nigama and Agama, Indian North and Indian South, the Aryans and Dravidians, Brahmins and inferior casts. Social aspect of Philosophy in India combines as a rule with caste and cultural diversity.

\section{REFERENCES}

[1] E. N. Anikeeva Problems of Indian Theism: Philosophical and Comparative Analysis. - Moscow: Orthodox St. Tikhon's Humanitarian University Publisher, 2013, p. 256.

[2] Pierre-Sylvain Filliozat. Preface // N. R. Bhatt. Shaivism In the Light of Epics, Puranas and Agamas. Varanasi: Indica Books, 2008. pp. 1116.

[3] Paranjoty Saiva Siddhanta. London: Luzac \& Co. 1td., 1954. - xxii, 152 p. P. xvii.

[4] P.-S. Filliozat, S. P. Narang, C. P. Bhatta, eds. Pandit N. R. Bhatt: Felicitation Volume. Delhi: Motilal Bnarsidass Pbls. Pv. ltd., 1994.

[5] N. R. Bhatt. Shaivism In the Light of Epics, Puranas and Agamas. Varanasi: Indica Books, 2008, p. 634 p.

[6] Dwivedi, R. Ghose, eds, Paramesvaragamah: Sanskrit text with English translation and notes. Varanasi: Shaiva Bharati Shodha Pratishthanam, 2004. - liii, 531 p. P. vi.

[7] Ibid., p. xxi.

[8] N. R. Bhatt. Shaivism In the Light of Epics, Puranas and Agamas, p. 43.

[9] E. N. Anikeeva, Foundations of Indian Religiosity: Dialectic of Personal-Impersonal. Moscow: People's Friendship University Publisher, 2010, p. 256.

[10] K. Satchidananda Murty, Philosophy in India: Traditions, Teachings \& Research. Delhi: Motilal Banarsidass, 1993. pp. 59-60.

[11] E.K. Gough Brahman Kinship in a Tamil Village. American Anthropologist. 1956, vol. 58, No. 5, pp. 826-853.

[12] E. N. Anikeeva, Problems of Indian Theism: Philosophical and Comparative Analysis (In Russian).

[13] Siva-nana-bodham: A Manual of Saiva Religious Doctrine /Trans. and interpreted by Gordon Matthews. Oxford, 1948, p. 5.

[14] The Nyayakusumanjali of Udayanacharya with Translation and Explanation by N. S. Dravid. Vol. I. New Delhi: Munshiram, 1996, pp. 369-370.

\footnotetext{
2 "Paraloka" differs from "alaukika" (Sans.): the former is "another world" in which the law of karma operates, e.g., heaven or hell; the latter means supernatural "out-of- this-world reality" above karma- samsāra functioning.
}

[15] Sivajnanabodha with the Laghuṭlka of SivagrayogI: Critically edited and Translated by T. Ganesan. Chennai, India: SrI Aghorasivacarya Trust, 2003. - xxvii, 74 p. P. 1.

[16] Siva-nana-bodham: A Manual of Saiva Religious Doctrine /Trans. and interpreted by Gordon Matthews, p. 19.

[17] The Nyayakusumanjali of Udayanacharya with Translation and Explanation by N. S. Dravid, p. 6. 